DOI: https://doi.org/10.4796o/2303-7431.24.2020.82

UDK: 004.738.5:811.11

811.111:371.3

Izvorni znanstveni članak

Primljen 16. VII. 2020.

Prihvaćen 6. IV. 2021.

Sunčana Tuksar - Moira Kostić Bobanović

Sveučilište Jurja Dobrile u Puli

suncana.tuksar@unipu.hr - moira.kostic.bobanovic@unipu.hr

\title{
INTERNET, MULTIMEDIJA I ULOŽEN TRUD PRI UČENJU ENGLESKOGA JEZIKA
}

\section{Sažetak}

U današnjem globalno umreženom društvu engleski je jezik lingua franca koju osobito promiče internet. U izravnoj (face-to-face) nastavi, a naročito u nastavi preko interneta (online), mediji prenose informaciju, jezik i kulturu pa se multimedijska, odnosno multimodalna komunikacija ističe kao nužna pri poticanju kritičke vizualne pismenosti i učenju engleskoga jezika. To je tako jer suodnos slike i teksta posreduje na način koji osnažuje pojedinčevu samosvijest o znanju jezika i kulture te aktivira njegov trud i angažman pri učenju. S obzirom na rečeno, cilj je ovoga rada ispitati sljedeće: a) uložen trud pri učenju engleskoga jezika te b) odnos uložena truda u face-to-face i online nastavu preko medija. Ispitivanje je provedeno na Sveučilištu Jurja Dobrile u Puli tijekom 2019./2020. akademske godine u razdoblju obvezna ostajanja kod kuće zbog pandemije koronavirusa. Ovakva i slična istraživanja ubuduće će biti važna za prožimanje medijski reprezentiranih informacija kao i za proširenje ili nadomjestak face-to-face nastave u uobičajenim komunikacijskim uvjetima ili u uvjetima kada je online nastava jedina opcija.

Ključne riječi: engleski; multimedija; informacija i komunikacija; face-to-face; online; trud 


\section{Uvod}

Vrlo općenito govoreći, danas živimo u vladavini slika; uronjeni smo u globalno umreženu kulturu pri čemu se engleski jezik nametnuo kao lingua franca, čiji globalan uspjeh osobito promiču internet i tehnološki napredak. Takva kultura participacije podrazumijeva sve veće korištenje multimedije u svakodnevnoj praksi. Upravo internet, kao neiscrpan izvor informacija, omogućuje platforme za održavanje online nastave. No tamo gdje rasprava uključuje jezik i medije, neupitan je i nužan teorijski okvir koji upućuje na multimodalni pristup pri učenju stranoga jezika. Točnije, u komunikacijskome multimedijskom obzoru jezik i kultura preko slika dovode se u suodnos. Kako bismo te odnose razumjeli i kontekstualno interpretirali, nužni su određeni segmenti sociolingvistike (cf. Crystal, 2007, 2018; Goodwyn, 2000; Trudgill, 1988) te sociosemiotike (cf. Burn i Parker, 2003; Jewitt et. al., 2016; Kress, 1998; Kress i van Leeuwen, 1996, 2000; Machin, 2007). Povezanost online komunikacije, medija, odnosno multimodalnih reprezentacija i uložena truda pri usvajanju engleskoga jezika prepoznaje i šira akademska zajednica: uvode se nove nastavne i znanstvene prakse, izravna nastava (u daljnjemu tekstu face-to-face) često se nadopunjuje ili posve mijenja s onom putem interneta (u daljnjemu tekstu online), odnosno sve se veća pozornost posvećuje nastavi posredstvom multimedije (cf. Bruno, 1997; Garcia-Pinar, 2019a, 2019b; Weiss, 2005, i dr.).

Dijalog o uloženome trudu pri učenju jezika traje već nekoliko desetljeća. Za početak, Gardner $(1985,1988)$ iscrpno govori o povezanosti stava i truda pri učenju jezika, razmatrajući pritom mogućnosti i probleme koji se u procesu učenja mogu javiti u odnosu na uloženi trud učenika. Također, o kontekstu uloženoga truda govorio je Dornyei (2005) koji je kod potreba i zakonitosti pri usvajanju jezika načelno usvojio Gardnerove teorije o individualnome kapacitetu uložena truda pojedinca pri usvajanju jezika. Naime, Gardner (2011) uspostavlja „okvire uma“ koji podupiru individualizirani pristup te ističu snagu kritičkoga mišljenja koje se razvija pri učenju, kako jezika tako i kulture (p. 82). Oba autora u prvome planu ističu retoričku snagu jezika, a potom i njegov eksplikativni 
potencijal pa je funkcija medijskoga teksta utoliko važnija zbog njegove retoričke, odnosno pokazivačke i uvjerljive komunikacijske snage. Drugim riječima, sve one karakteristike učenja koje se prema navedenim autorima nužno odvijaju preko jezika, poput davanja i primanja pismenih i/ili usmenih informacija, dakle uputa i objašnjenja, sada se naprosto mogu snagom slike-kao-dokaza vidjeti. Sve u svemu, počevši od kanona do recentnijih istraživanja, učenje će time biti uspješnije ako pojedinac želi učiti, odnosno ako pri tome uživa jer će istovremeno uložiti svojevrstan napor te će, svakako, trud utjecati na rezultate (cf. Gardner, 1985, 1988; Huftonet. al., 2002; Gardner, 2011; Siegel, 2015). Danas su mnogi istraživački principi nezamislivi bez uključivanja multimedije. S jedne strane, multimodalnost pretpostavlja medijsku proizvodnju modusa ili kodova različitih sociokulturnih značenja, ali i poziva na njihovu daljnju kulturološko-jezičnu interpretaciju pa se kultura doživljava kao nužno potreban kontekst u formalnome okruženju učenja jezika. S druge strane, studenti uronjeni $\mathrm{u}$ medije ili uključeni u online nastavu mogu je doživjeti na jednak način kao i nastavu face-to-face (cf. Montiel-Chamorro, 2018) te čak biti dodatno motivirani za učenje jezika pri izvođenju online nastave (cf. Harnett, 2016).

S obzirom na intenzivno korištenje medija, digitalnoga teksta te online nastave, kojoj se odnedavno pristupilo zbog globalne zaraze virusom COVID-19 ${ }^{1}$, došlo je do novih potencijalno znanstveno zanimljivih mogućnosti istraživanja jezika posredstvom medija, kako u humanističkome tako i u njemu bliskome društvenom području. Kao primjer može poslužiti ispitivanje u ovome radu, provedeno upravo u razdoblju epidemije koronavirusa na Sveučilištu Jurja Dobrile u Puli u 2019./2020. akademskoj godini, kojim su se željeli ispitati stavovi studenata o uloženome trudu pri učenju engleskoga jezika, odnosno o odnosu uložena truda u face-to-face i online nastavu, tj. digitalnu komunikaciju. Bitno je napomenuti da je slično istraživanje proveo i Istifci (2017). Naveo je

U Republici Hrvatskoj razdobljem zaraze i stroge (samo)izolacije te zabrane kretanja (engl. the lockdown) službeno se smatra razdoblje od 18. ožujka 2020. do 1. svibnja 2020. Više o tome može se pronaći na službenim stranicama Grada Zagreba te Zavoda za javno zdravstvo Republike Hrvatske, <https://www.zagreb.hr/vazna-obavijest-covid19/156368>; <https://www.hzjz.hr>. 
da dublje razumijevanje percepcije studenata i uložena truda vodi pojmu „udružene nastave“ (engl. blended learning), koja spaja i uključuje i online i face-to-face nastavu, a takav komunikacijski model nastave, prema stavovima studenata, pridonosi učenju u različitim domenama. U naznačenome kontekstu dva su osnovna polazišta ovoga rada. Prvo je da vladavina multimedije i digitalne komunikacije potiču želju za učenjem općenito, a zatim i učenje engleskoga jezika partikularno. Drugo je polazište bilo da je ovladavanje jezikom potrebno sagledavati unutar sociosemiotičkih (društvenih, kulturoloških) edukacijskih modela koji djeluju i ovise o pragmatičkoj dimenziji pojedinčeva truda. U tome se smislu ovim radom evaluiraju ključna pitanja uložena truda kako bi se uvela daljnja rasprava na tragu komunikacijske i kulturološke interpretacije suodnosa slike i jezika, odnosno vizualne pismenosti u nastavi. Naposljetku, rezultati istraživanja potvrđuju ovu nakanu jer su pokazali kako su studenti za vrijeme online nastave koncentriraniji, čime se ukazuje da multimodalne reprezentacije mogu imati važnu ulogu pri uloženu trudu kod učenja engleskoga jezika.

\section{Teorijske spoznaje}

Uronjenost u digitalnu sferu nesumnjivo se dovodi u svezu s multimedijom, stoga suodnos modusa (verbalnih i vizualnih elemenata) poziva na sociosemiotičku interpretaciju te upućuje na daljnja sociolingvistička razmatranja. Tomu je tako jer je engleski jezik globalna lingua franca, čime se trud pri učenju jezika i neposredna uključenost u multimedijske sfere nesumnjivo dovode u svezu preko komunikacije. Mnogi su autori osvijestili tu dimenziju učenja jezika, odnosno prihvatili pojavu da se rasprava o jeziku tiče komunikacije koja uključuje jezik, kulturu i medijski posredovanu informaciju.

\subsection{Multimodalna komunikacija, lingua franca i trud pri učenju jezika}

Kažemo da su mediji multimodalni jer multimodalna komunikacija podrazumijeva skupine verbalnih i vizualnih reprezentacija (modusa) 
koji svojim suodnosima kreiraju određena značenja unutar (medijskoga) teksta te prenose poruku, odnosno informaciju. Takav suodnos slike i teksta počesto dizajnira digitalnu stvarnost, a ona pak prenosi određenu spoznajnu i kulturološku, odnosno ideološku vrijednost. U najširemu smislu takvo premišljanje predstavlja pomak od strukture, odnosno jezika prema svim digitalnim formama. Zapažanje da je slika tekst poznato je od ranije, a tomu u prilog govore i znanost o slici (cf. Burke, 2003), semiotika (cf. Noth, 2004), a u novije vrijeme i multimodalna sociosemiotika, čija je nakana preispitati tradicionalno poimanje teksta pomoću adekvatne kulturološke interpretacije (cf. Kresset. al., 1998; Kresset. al., 2001; Van Leeuwen, 2005; Machin,2007; Jewittet. al.,2016; Burn i Parker, 2003). U današnje doba multimodalni tekst nalazimo svuda oko nas, primjerice na društvenim mrežama, mrežnim stranicama, u filmu, stripu, crtežu, reklamama, mrežnim blogovima, pa čak i u pismu, fontu ili e-poruci. Jednostavnije, gdje je međuodnos modusa, tu su multimodalne reprezentacije, a samim time i komunikacija, odnosno kulturološka interpretacija.

Služeći se tekstovima na mrežnim stranicama, bili oni slikovni ili tradicionalni, uvidjet ćemo da je engleski jezik u povlaštenome položaju u odnosu na sve druge jezike. Razlog je tomu činjenica da je engleski jezik globalna lingua franca te se kao takav mijenjao i razvijao usporedno s razvojem medijskih i tehnoloških inovacija, odnosno da upravo internet promiče njegovu globalnu popularnost. Prema mnogim sociosemiotičarima, multimedija unosi nove elemente te posreduje kronici jezičnih i kulturoloških promjena, osobito u smislu multikulturalnosti i globalno povezana, umreženog društva (cf. Van Leeuwen, 2005). No takav pristup nije nužan samo u tome području. Naime, kada je riječ o trudu pri učenju engleskoga jezika, na tome su tragu i lingvisti, odnosno sociolingvisti. Primjerice, Crystal (2007), govoreći o engleskome jeziku i medijima, ističe i računalno posredovanu komunikaciju (engl. Computer mediated communicaton - CMC), odnosno podsjeća da ne postoji samo onaj „rukom pisani tekst“, nego i onaj medijski (pp. 97-153). Nadalje, poticaj na rad putem raznih medija i platformi, online nastave uopće, dovodi do odnosa online učenja i interpretiranja jezika u društvenome 
kontekstu i interakciji. Pri tome Trudgill (1982) ističe engleski kao dominantan jezik u određenim kulturama te napominje da je engleski, kao uostalom svaki jezik, u suodnosu s društvenim kontekstom te da je novi verbalni repertoar globalno umrežena društva danas gotovo bilingvalan (p. 123). Time ovaj autor smatra da jezik, odnosno određena društva i društvene aktivnosti, sa sobom nose kontekst koji uvjetuje teme razgovora u kojima se stilovi i registri izmjenjuju, a formalni i neformalni stilovi miješaju (pp. 100 - 101). Na tragu je takva razmišljanja i Weiss (2005) koji se, govoreći o engleskome jeziku i globalnoj kulturi, načelno referira na njegovu internacionalnu dispoziciju kojom se preko interneta obraća globalnoj publici. Engleski time osigurava univerzalan jezik, a internet medijski prostor kao globalnu sociokulturnu participativnu sredinu (pp. 1 - 10).

Upravo se uronjenost u medije danas može smatrati, barem donekle, prirodnim kontekstom. Sagledavajući aspekte procesa ovladavanja jezikom, još je Gardner (1988) uočio važnost sociokulturne sredine rekavši da će prirodan kontekst posredovati pri usvajanju jezika u smislu kognitivnih i afektivnih činitelja uslijed kojih će pojedinac uložiti trud tijekom učenja. Ako se potakne želja, smatra Gardner, pojedinac će uživati u učenju jezika, željet će ga naučiti te samim tim uložiti i napor (pp. 101 - 126). Na tome modelu razvili su se mnogi daljnji modeli, poput empirijskih istraživanja u području motivacije i uspjeha kod pojedinaca u učenju jezika (cf. Dornyei - Csizer, 1998) ili pak rasprava o potrebi za postignućem ovisno o sadržaju predmeta (kurikulumu) te nastavnim materijalima i, ponovno, kontekstu (cf. Dornyei, 2005). Jednim od nedostataka Gardnerovih teorija smatrala se nedovoljna primjenjivost $u$ nastavnoj praksi. Zbog toga su Dornyei i Csizer (1998), sistematizirajući motivacijske tehnike studijom provedenom među nastavnicima drugoga jezika, procijenili strategije koje su doista relevantne za poticaj pri učenju jezika, poput prikladno predočena zadataka, rada na povećanju pojedinčeva samopouzdanja, osiguravanja konteksta, odnosno poticajne radne okoline te upoznavanja kulture ciljanoga jezika (pp. 205-207). Nadalje, novija su se istraživanja pedagoški preusmjerila na uložen trud i razne tehnike pri učenju i samoj nastavi. Tako su Hufton et. al. (2002) 
zaključili da je sposobnost svakako važna, ali i kako se uloženim trudom mogu postići željeni rezultati. Ti autori upravo trudu pripisuju uspjehe kod učenja jezika, dok prirodnomu talentu pripisuju daljnju distinkciju između vrhunskih i ostalih studenata. I Siegel je govorio o trudu (2015), ali ne samo kod učenika nego i nastavnika. Uvodeći nove pedagoške strategije, autor se usmjerio na vještinu slušanja i predstavio taksonomiju odabira post hoc umjesto ad hoc, točnije, nastavnik ispituje razumijevanje nakon slušanja i obradbe određena teksta (pp. 57 - 58). Nastavnik obradbom teksta / slušanjem podupire proces učenja, vodi i usmjerava nastavni proces, a time se uobičajena analiza tekstnoga sadržaja prenosi izvan konteksta učionice. Ukupan nastavnikov trud pomoću ranije zanemarenih principa i pristupa koje Siegel (2015) predstavlja posreduje prilikom transfera metode slušanja i omogućuje njegovu daljnju primjenu (pp. $59-65$ ).

Dakle, globalno umrežena kultura osigurava zanimljiviji i suvremeniji pristup nastavi, što izravno utječe na uložen trud. Imajući na umu sve navedeno, trud će se potencijalno uložiti s izgradnjom pojedinčeva samopouzdanja, čime će se postići i njegova usredotočenost. Osim utjecaja interneta, zaključuje Weiss (2005), taj proces potvrđuje činjenica da je engleski jezik internacionalno prepoznatljiv, a da je njegov korisnik „tipičan spisatelj i čitatelj na engleskome jeziku sve više upravo onaj tko je ga uči kao strani jezik“, te da će „do sredine 21. stoljeća većina zemalja koja ima službeni drugi jezik odabrati upravo engleski jezik kao drugi jezik"(p. 5).

\subsection{Multimedija i usvajanje jezika u akademskome okruženju}

U prethodnome poglavlju ustanovljeno je da je engleski jezik globalan (cf. Crystal, 2008; Trudgill, 2005; Weiss, 2005) te da su njime udružene višejezične zajednice. Zbog svojega univerzalnog utjecaja engleski je lingua franca, a zahvaljujući ubrzanu razvoju tehnologije, jezik, mediji i kultura u neposrednoj su svezi. Zbog toga je potrebno sagledati nove principe online učenja i multimodalnih odnosa koji unutar društvenoga konteksta pridonose uloženomu trudu pri učenju jezika. Naposljetku, 
ako je engleski jezik reprezentacijska sila kojom se svi, barem donekle, služe, tada je potrebno steći i daljnja znanja o raspravama koje se pri tome otvaraju, a povezuju jezik i kulturu (cf. Trudgill, 1982).

U internacionalnome akademskom obzoru uvriježeni su pristupi korištenja raznih medija za posredno i neposredno proučavanje i podučavanje. U turizmu i kulturi Bruno (1997) proučava semiotiku geografije i arhitekture na filmu, čime kroskulturalno dovodi u svezu medijski prostor i svakodnevicu. Na sličnu su tragu Rarick (2007) i Roell (2010) koji, premrežujući humanističko i društveno područje, koriste film u nastavi kao multimodalni tekst za usvajanje interkulturalnih kompetencija. S druge strane, Zollo (2019) istražuje i podučava multimodalnost u kontekstu kulture i diskursa i kao strategiju za razvoj kritičkoga mišljenja, smatrajući kako time studente potiče da ulože dodatni trud pri učenju jezika. Navedeni primjeri ukazuju da multimedija u nastavnoj praksi načelno pomaže pri pronalaženju jednoga od mnogih odgovora na pitanje: „Što je to kultura?“ Također, praksa posljednjih nekoliko desetljeća pokazuje kako se posredstvom multimedije pokreću nove ideje te da znanje o kulturi potiče na učenje jezika u suvremenome okruženju, što dodatno potvrđuje notorna činjenica kako se udžbenik već dulje vrijeme smatra zastarjelim (cf. Bird et. al., 1999). Istraživanja u svezi s online učenjem jezika pružaju uporište kada je riječ o usporedbi postignutih rezultata te čak ukazuju na donekle superiornu poziciju u odnosu na face-to-face nastavu. Rezultati mogu čak sugerirati ne samo da studenti doživljavaju online učenje na jednak način kao i ono u školskome okruženju nego i da postižu bolje rezultate (cf. Montiel-Chamorro, 2018).

U tome smislu osobito je zanimljiv istraživački pristup Garcia-Pinar (2019a; 2019b), koja proučava uloženi trud pri učenju engleskoga jezika posredstvom online predavanja - TED. Riječ je o multimodalnoj komunikaciji i angažmanu studenata, a ispituje se utjecaj multimodalnih reprezentacija na samosvijest studenata i posljedično uložen trud pri komuniciranju na engleskome jeziku (pp. 231 - 253). Naime, TED predavanje vrsta je javnoga izlaganja (engl. publicspeaking), stoga studenti tijekom učenja jezika ujedno mogu vidjeti izvedbu predavanja. Garcia-Pinar smatra da su TED predavanja svojom multimodalnošću danas 
važni alati za diseminaciju informacija u online prostoru. Nebrojene su mogućnosti takve komunikacije jer se povezuje više različitih vizualnih i verbalnih modusa, a studenti mogu interaktivno sudjelovati tako što istražuju izvedbe određenoga online predavanja gestama, izrazima lica, blizinom i prostornošću ili pak prozodije - ritma, stanki ili melodije govora. Autorica u svome radu preporučuje da se ne treba pitati što je bolje: knjiga ili zaslon, nego je ispravno pitati što je bolje u koje svrhe (cf. Jewitt, 2016 ; Garcia-Pinar, 2019a, pp. 231 - 253).

Zajedničko je svim navedenim autorima da posredno ili neposredno koriste medije i multimodalnost, a pritom nastoje uključiti komponentu truda. Unutar ranije spomenutoga socioedukacijskog modela Gardner $(1985,1988)$ ispituje motivaciju pri ovladavanju jezikom, pri čemu motivaciju smatra složenim konceptom unutar kojega su važni stav i želja za učenjem. Uz socijalne i kontekstualne čimbenike, autor uvelike posvećuje pažnju i kognitivnim procesima, stoga jasno razlikuje aspekte temeljene $\mathrm{u}$ individualnim razlikama, kako biološkim i iskustvenim (poput spola, dobi ili povijesti učenja) tako i u kognitivnim (stav, motivacija, stav i dr.). Međutim, u formalnome kontekstu pružanja informacije svi će ti čimbenici djelovati zajedno te će u pragmatičkoj dimenziji tražiti svojevrsnu nadogradnju. Upravo se prilikom nadgradnje pomiču granice učenja, o čemu govori i Dornyei (2005), koji, analizirajući trud, upućuje svojevrsnu kritiku Gardnerovu modelu. Na tragu svojih empiričkih istraživanja motivacije pri usvajanju jezika Dornyei prvenstveno govori o iskustvenome putu učenja jezika koji se odnosi na neposrednu okolinu i kontekst, a čine ga nastavnik i ostali sudionici u procesu učenja. Također, Dorneyei ističe nastavni kurikulum kao izuzetno važan jer su nastavni programi i materijali učestalo standardni promatrački konstrukt koji se u svakome slučaju mora razvijati.

U ovome razvojnom dijelu sagledava se, dakle, interaktivno i participativno (medijski potpomognuto) učenje kao suvremeni segment neposredna iskustva. U svezi s tim važnost engleskoga jezika u globalno umreženome društvu Goodwin (200o) propituje u odnosu na čitanje i pisanje te kontekstualizaciju jezika unutar elektroničkih medija (p. 115). Kada je riječ o uloženu trudu, zanima ga kako će se mediji i računalna 
tehnologija analitički odraziti na engleski jezik te zbog toga istražuje izazove $s$ kojima se učenici suočavaju uronjeni u digitalne tekstove, načine na koje mogu svojim trudom doseći svoje potencijale i, naposljetku, hoće li i kako dinamični digitalni tekstovi nagnati učenike da ulože dodatni trud. Goodwin (200o) vjeruje da će se navedeno ostvariti, a pritom ističe upravo učitelja kao "nositelja novih znanja u digitalnome dobu“ (pp. 1 - 22), dok učenike na simboličkoj razini naziva „umjetnicima" koji, služeći se mrežom tekstova koji uspostavljaju odnos, potiču kreativnost (p. 115).

\section{Cilj istraživanja}

Uložen trud važan je čimbenik pri učenju engleskoga jezika. Uzimajući u obzir teorijske uvide, nastava face-to-face i nastava online obilježene su uloženim trudom koji podrazumijeva da se informacije pamte, da se uči s razumijevanjem te da se problemski pristup rješava samostalno ili pomoću učitelja. U tome je smislu primaran cilj ovoga istraživanja bio ispitati stavove studenata o uloženome trudu te odnos između uloženoga truda u face-to-face i online nastavi. Istraživanje je potaknuto nedavnim iskustvom koje je na globalnoj razni nametnulo pojačano korištenje online komunikacije u nastavi u pragmatičnome dijelu ${ }^{2}$ kao i važnom činjenicom kako je taj aspekt u takvim zadanim okolnostima nedovoljno ili nimalo istražen i zastupljen u znanosti. Do novih se znanstvenih spoznaja došlo formiranjem sljedećih istraživačkih pitanja/ciljeva:

1) Koliki je trud uložen pri učenju engleskoga jezika?

2) Postoji li razlika između uložena truda pri učenju engleskoga jezika u izravnoj nastavi (face-to-face) i nastavi koja se odvija putem interneta (online)?

Pandemija virusa COVID-19 okvirno je zahvatila Republiku Hrvatsku od 18. 3. 2002. do 1. 5. 2020., s time da se online nastava nastavila održavati i nakon toga razdoblja, a pri naznačenome Sveučilištu do kraja tekuće 2019./2020. akademske godine. 


\section{Metodologija istraživanja}

U ovome će se poglavlju podrobno opisati metodologija provedena istraživanja: ispitanici, upitnik korišten u istraživanju te sam istraživački postupak. Rezultati istraživanja analizirali su se i interpretirali. Istraživačka je metoda bila upitnik, odnosno ispunjavanje ankete o uloženome trudu pri učenju engleskoga jezika face-to-face (izravna nastava) i online (nastava preko interneta).

\subsection{Uzorak}

U istraživanju su sudjelovali studenti Sveučilišta u Puli koji su učili engleski kao strani jezik na drugoj i trećoj godini studija. Istraživanje se provelo u drugome semestru akademske godine 2019./2020., dok se nastava održavala online (cf. fusnote 1 i 2 ).

Uzorkom su obuhvaćena ukupno 263 studenta, a prosječna dob ispitanika koji su sudjelovali u anketnome upitniku bila je od 21 do 23 godine. Opis broja i postotaka sudionika s obzirom na spol nalazi se $\mathrm{u}$ Tablici 1. U uzorku je zastupljeniji muški spol, 164 (624,7 \%), u odnosu na ženski, 99 (37,6\%).

Tablica 1. Broj i postotak sudionika s obzirom na spol:

\begin{tabular}{|l|l|l|}
\hline Spol & N & $\%$ \\
\hline Ženski & 99 & 37,6 \\
\hline Muški & 164 & 62,4 \\
\hline Ukupno & 263 & 100 \\
\hline
\end{tabular}

\subsection{Ispitivanje stavova o uloženome trudu pri učenju engleskoga jezika}

U narednome poglavlju opisana je korištena metoda istraživanja (metoda anketiranja). Uloženi trud pri učenju engleskoga jezika mjerili smo upitnikom preuzetim iz Gardnerova i Lambertova istraživanja (cf. Gardner, 1985). Upitnik se sastoji od deset tvrdnji s višestrukim izborom, a uz svaku tvrdnju nalazi se skala slaganja od pet stupnjeva, a svoje 
slaganje ili neslaganje s tvrdnjama izražavali su zaokruživanjem brojeva: od jedan (1) - ne slažu se s tvrdnjom, do pet (5) - sasvim se slažu s tvrdnjom.

Tvrdnje u upitniku u svezi su $\mathrm{s}$ ispitanikovim zalaganjem na satu te njegovim odnosom prema radu i nastavi. Studentima je objašnjena struktura anketnoga upitnika te je posebno istaknuta anonimnost njihovih odgovora. Anketiranje se provelo na zadnjemu satu nastave engleskoga jezika.

\section{Analiza rezultata i rasprava}

Nakon prikupljanja svih podataka uslijedila je statistička analiza varijabli obuhvaćenih istraživanjem. Statistička analiza obaju upitnika provedena je pomoću programskoga paketa SPSS for Windows 17.0 (Statistical Package for Social Sciences).

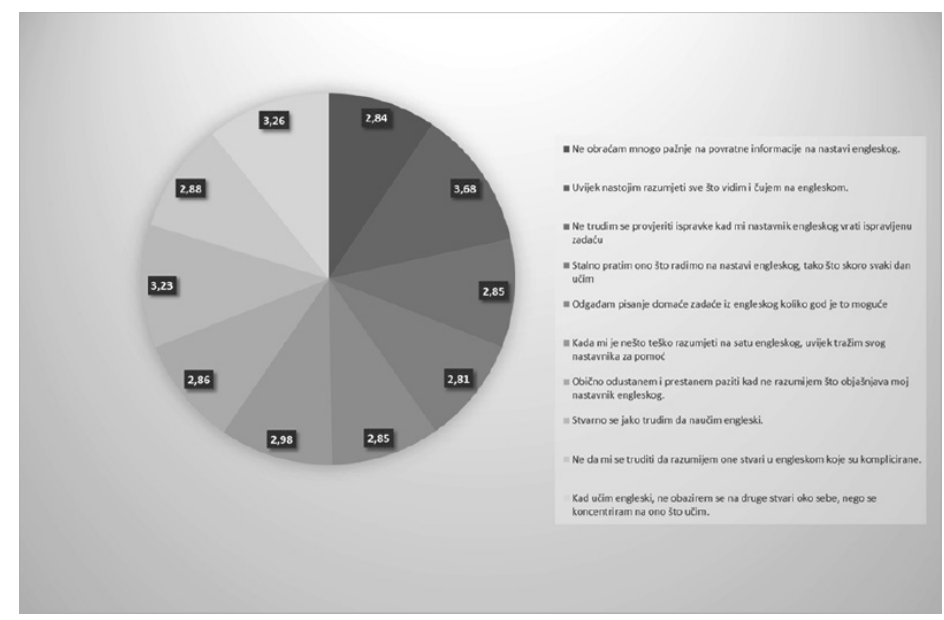

Grafikon 1. Aritmetička sredina i standardne devijacije upitnika uložena truda pri učenju engleskoga jezika

Prosječni rezultati koje su postigli ispitanici $(n=263)$ prikazani su u Grafikonu 1. Minimalan ukupan rezultat u upitniku bio je 10, a maksimalan 50. Koeficijent pouzdanosti ovoga upitnika (Cronbach Alpha) iznosi o,82. Prema navedenim rezultatima možemo zaključiti da većina ispitanika ulaže velik trud pri učenju engleskoga jezika $(m=3,23)$. 
Najveća je ocjena za tvrdnju Uvijek nastojim razumjeti sve što vidim $i$ čujem na engleskom ( $\mathrm{m}=3,68)$, s kojom se studenti uglavnom slažu. Studenti nastoje zapamtiti informacije koje dobiju na satu te učiti s razumijevanjem. Najmanja je ocjena u svezi s tvrdnjom Stalno pratim ono što radimo na nastavi engleskog, tako što skoro svaki dan učim $(\mathrm{m}=$ 2,81). Pretpostavljamo da studenti više uče neposredno prije kolokvija i ispitnih rokova, a ne svakodnevno. Nadalje, studenti nastoje na vrijeme napisati domaću zadaću te se trude provjeriti ispravke kada im nastavnik engleskoga donese ispravljenu zadaću. Isto tako, trude se razumjeti i zahtjevnije sadržaje, a ako naiđu na poteškoće u radu, obrate se predmetnome nastavniku. Zanimljiv je iznenađujuće visok rezultat tvrdnje Kad učim engleski, ne obazirem se na druge stvari oko sebe, nego se koncentriram na ono što učim $(\mathrm{m}=3,26)$, čime se pokazalo da su studenti zainteresirani za učenje te da uslijed motiviranosti, vjerojatno, proizlazi i koncentracija.

Nakon provedene deskriptivne statistike provedena je analiza varijance kako bi se ustvrdilo postoje li razlike između aritmetičkih sredina upitnika o uloženome trudu pri učenju engleskoga jezika tijekom face-to-face nastave i online nastave.

Tablica 2. Razlike u uloženome trudu pri učenju engleskoga jezika između face-to-face nastave $i$ online nastave $(n=263)$ :

\begin{tabular}{|l|c|c|c|c|}
\hline Uloženi trud pri učenju engleskog jezika & $\begin{array}{c}\text { Face- } \\
\text { to-face }\end{array}$ & $\begin{array}{c}\text { On } \\
\text { line }\end{array}$ & & \\
\hline $\begin{array}{l}\text { 1. Ne obraćam mnogo pažnje na povratne } \\
\text { informacije na nastavi engleskog. }\end{array}$ & 2,53 & 2,66 & 0,99 & 0,74 \\
\hline $\begin{array}{l}\text { 2. Uvijek nastojim razumjeti sve što vidim i čujem } \\
\text { na engleskom. }\end{array}$ & 3,68 & 3,42 & 1,94 & 0,68 \\
\hline $\begin{array}{l}\text { 3. Ne trudim se provjeriti ispravke kad mi } \\
\text { nastavnik engleskog vrati ispravljenu zadaću. }\end{array}$ & 2,57 & 2,32 & 1,83 & 0,49 \\
\hline $\begin{array}{l}\text { 4. Stalno pratim ono što radimo na nastavi } \\
\text { engleskog, tako što skoro svaki dan učim. }\end{array}$ & 2,79 & 2,68 & 0,94 & 0,23 \\
\hline $\begin{array}{l}\text { 5. Odgađam pisanje domaće zadaće iz engleskog } \\
\text { koliko god je to moguće. }\end{array}$ & 2,95 & 2,17 & 1,94 & $\mathbf{0 , 0 1}$ \\
\hline
\end{tabular}




\begin{tabular}{|l|c|c|c|c|}
\hline $\begin{array}{l}\text { 6. Kada mi je nešto teško razumjeti na satu } \\
\text { engleskog, uvijek tražim svog nastavnika za } \\
\text { pomoć. }\end{array}$ & 2,99 & 2,07 & 2,01 & $\mathbf{0 , 0 1}$ \\
\hline $\begin{array}{l}\text { 7. Obično odustanem i prestanem paziti kad } \\
\text { ne razumijem što objašnjava moj nastavnik } \\
\text { engleskog. }\end{array}$ & 2,86 & 2,41 & 1,93 & 0,08 \\
\hline 8. Stvarno se jako trudim da naučim engleski. & 3,24 & 3,08 & 1,03 & 0,45 \\
\hline $\begin{array}{l}\text { 9. Ne da mi se truditi da razumijem one stvari u } \\
\text { engleskom koje su komplicirane. }\end{array}$ & 2,86 & 2,77 & 1,98 & 0,33 \\
\hline $\begin{array}{l}\text { 10. Kad učim engleski, ne obazirem se na druge } \\
\text { stvari oko sebe, nego se koncentriram na ono što } \\
\text { učim. }\end{array}$ & 3,06 & 3,72 & 1,93 & $\mathbf{0 , 0 0}$ \\
\hline
\end{tabular}

$(p<0,01)$

U Tablici 2 uspoređen je uložen trud pri učenju engleskoga jezika face-to-face i u online nastavi. Kod većine tvrdnji u obje skupine rezultati su podjednaki, odnosno nema statistički bitnih razlika između face-to face i online nastave, čime se može zaključiti da u oba slučaja studenti podjednako obraćaju pozornost na povratne informacija kao i da nastoje razumjeti sve što vide i čuju na engleskome te se trude provjeriti ispravljenu zadaću. Naposljetku, u obje skupine rezultati su pokazali da studenti kontinuirano prate nastavu te redovito uče i trude se ovladati engleskim kao stranim jezikom.

S druge strane, statistički bitnu razliku između dviju inačica nastave čine tri tvrdnje od ukupno njih deset, a to su tvrdnje broj 5, 6 i 10. Rezultati $t$-testa ukazuju na postojanje statistički bitne razlike u tvrdnji br. 5: Odgadam pisanje domaće zadaće iz engleskog koliko god je to moguće $(\mathrm{t}=1,94 ; \mathrm{p}<\mathrm{0}, 01)$. Analizirajući rezultate, možemo vidjeti da studenti bitno više odgađaju pisanje domaće zadaće kada je riječ o face-to-face nastavi nego online. Razlog tomu može biti da nisu sigurni hoće li stići odraditi zadatke na vrijeme, a moguće je da na navedeno dodatno utječe neizravan kontakt $\mathrm{s}$ nastavnikom kao i izolacija od formalnoga konteksta nastave (individualno praćenje od kuće). Moguće je da takav novouspostavljeni odnos online nastave utječe na potrebu studenata da ulože dodatan trud kako ne bi zaostali s gradivom. 
Nadalje, uvidom u Tablicu 2 možemo zaključiti da postoji statistički bitna razlika u tvrdnji 6: Kada mi je nešto teško razumjeti na satu engleskog, uvijek tražim svog nastavnika $(\mathrm{t}=2,01 ; \mathrm{p}<0,01)$. Potrebno je dodatno proučiti te analizirati zbog čega studenti kada nešto ne razumiju, radije traže dodatnu pomoć kada je riječ o face-to-face nastavi nego o online nastavi. Razlog tomu može biti nedostatak ili potpuno izuzeće neverbalne komunikacije koju face-to-face nastava omogućuje. Također, nedostatak neverbalne komunikacije može pridonijeti osjećaju srama i nesigurnosti jer izostaje potvrda nastavnika ili drugih studenata, primjerice neki pokret ili pogled, koja može biti znak ohrabrenja.

Izostanak toga uzrokovat će nerazumijevanje pa, shodno tomu, i nesigurnost pri izričaju. Drugi je moguć razlog problematika pisanja. Načelni je zaključak da računalno posredovana komunikacija nastoji imitirati oba svojstva jezika, govor i pisanje, i kao takvu autori je smatraju novim oblikom komunikacije. No, kod govorenja i pisanja u online nastavi do izražaja dolazi činjenica kako postoji određeno vremensko ograničenje posjećenosti stranice ili redoslijeda u dijalogu. S druge strane, računalno posredovano pisanje nije zamjena klasičnomu načinu pisanja, jer, kao prvo i osnovno, nedostaje "fiksnost stranice“ na koju nešto ispisujemo rukom, zatim tekst nije statičan i trajan, nadalje takvo je pisanje podložno intervenciji i izmjenama te, naposljetku, internetske stranice mogu varirati od „susreta“ do "susreta“ odnosno posjećenosti (Crystal, 2007: 156 - 158). Nenavikli na takav oblik računalno posredovane komunikacije, koji je svojevrstan hibrid proizašao iz medija jezika, studenti nevoljko traže pomoć.

Naposljetku, zanimljivi su rezultati tvrdnje 10: Kad učim engleski, ne obazirem se na druge stvari oko sebe, nego se koncentriram na ono što učim $(\mathrm{t}=1,93 ; \mathrm{p}<\mathrm{o}, 00)$. Analizirajući rezultate Tablice 2, uvidjeli smo da su studenti statistički bitno koncentriraniji kada je riječ o online nastavi nego face-to-face nastavi. Objašnjenje možemo potražiti upravo u interaktivnosti online nastave, pri čemu studenti često prate nastavu sa slušalicama, orijentirani su na sučelje te je moguće da im pri tome ništa ne odvraća pažnju. Također, zasigurno je jedan od razloga i svojevrsna uronjenost u medije kojom se sudionici isključuju iz ostalih aktivnosti 
i prilikom potrage za informacijama izrazito su koncentrirani na aktivnosti koje se odvijaju na ekranu.

Sagledavši ukupnu analizu rezultata, uputno je predvidjeti moguću problematiku u budućnosti. S jedne strane, studentima - korisnicima interneta ili online nastave predstoje izazovi koje je pretpostavio Gardner $(1985,1988)$, dakle oni koji se odnose na samu motivaciju. Krenuvši od ranije uspostavljenih postulata, o motivaciji je govorio i Harnett (2016), osvrnuvši se pritom na intrinzičnu (unutarnju) motivaciju studenata. Usporedbom online nastave s onom koja se izvodi klasičnim putem Harnett je došao do rezultata koji pokazuju da su studenti pri online nastavi motiviraniji, što je objasnio time da online učenje samo po sebi stvara okruženje za koje je intrinzična motivacija nužna u smislu znatiželje i samoregulacije uložena truda. S druge strane, predstoje izazovi koji podrazumijevaju digitalnu korisnikovu participaciju, odnosno dinamiku odnosa koji se odvijaju u interaktivnoj participativnoj kulturi u smislu poticaja i motivacije (cf. Goodwyn, 20oo; Trudgill, 1988; Van Leeuwen, 2005). Primjerice, kada je riječ o online nastavi, nesigurnost i posljedični nedostatak motivacije može uzrokovati opća tehnička problematika (povezanost, tehnički detalji, mreža i sl.). O tome je bilo riječi i kod Harnetta (2016) koji je upravo tehnološke dvojbe povezao s mogućim izvorom frustracija kod studenta te posljedično nedostatak motivacije za rad. Isto tako, potrebno je uzeti u obzir i problematiku vizualne pismenosti, odnosno (ne)razumijevanja nužno potrebnih kulturoloških tumačenja multimodalnih odnosa. Nadalje, u pogledu jezika, razgovora i komunikacije na engleskome jeziku, kod govora može doći do usporavanja komunikacije zbog čekanja na rad za uključenje u online nasta$\mathrm{vu}$, što može poremetiti ritam razgovora i koncentraciju. Sve navedeno može se dovesti u svezu s ometanjem pozornosti; a kao rezultati mogući su nerazumijevanje ciljeva nastave, pomanjkanje osobnoga interesa, nesigurnost u svezi s uporabom jezika te nadasve smetnje u komunikaciji i/ili konverzaciji.

Kako bilo, rezultati našega istraživanja tijekom pandemije koronavirusa u podudarnosti su s upitnikom i istraživanjem provedenim na sveučilištu u Turskoj prije izvanrednih okolnosti (cf. Istifci, 2017). Ispitujući 
studentsku percepciju, autor je analizom pokazao da se studentima sviđa format udružene nastave, odnosno one koja kombinira online i face-to-face nastavu. Dok učenicima online nastava pruža fleksibilnost pri radu i pohađanju predavanja, kao i pri korištenju online platformi za učenje jezika, pri samoj komunikaciji radije imaju izravan kontakt s profesorom i ostalim studentima. Donekle je, dakle, izvjesno da je udružena nastava doista najprihvatljivije rješenje u studentskoj percepciji jer kombinira više različitih pristupa i komunikacijskih formata koji ponaosob posreduju u poticanju na rad i obnašaju funkcije neophodne za uspješno savladavanje engleskoga jezika.

Naposljetku, točno je da je engleski lingua franca koju govore mnogi neizvorni govornici. U skladu s društvom participacije, sustavna interpretacija društvenih, kulturoloških i jezičnih praksi upravo je zbog takva rutinskog sudjelovanja na globalnoj razini postala nužnost. Međutim, slabost takva pristupa engleskomu jeziku mantra je da „engleski svi govore“, odnosno smatra se općeprihvatljivim da širokopojasna rasprostranjenost engleskoga jezika podrazumijeva da je svima ujedno dostupan i razumljiv. Naravno da tomu nije tako te da takav pristup može predstavljati opasnost pri potrebi da se razumijevanje i jezika i kulture produbi, nadogradi te da vizualne reprezentacije ne služe samo u svrhu promatranja nego dubljega interpretativnog razumijevanja.

$\mathrm{Na}$ taj bi se način i na toj razini potaknuo dodatno uložen trud, jer bi put razvoja kritičke misli ujedno bio i put koncentracije na jezik kao takav pa onda i na njegovo (čak usputno) usvajanje. Stoga se multimodalni pristup - komunikacija putem multimedije - nameće kao nužan pri odabiru daljnjega istraživačkog puta za online nastavu i razumijevanje informacija uopće. Što se tiče razvoja interesa kod sudionika nastavnoga procesa, cilj je pružiti generalni okvir unutar kojega se osigurava pristup koji povezuje režim slika, odnosno medije s učenjem jezika. Time dolazi do sinergije između multimedije i jezika, odnosno do proširivanja i razumijevanja komunikacije i informacije pri učenju stranoga jezika na putu do stjecanju daljnjih znanja o/u globalno umreženoj kulturi. 


\section{Zaključak}

Engleski je jezik lingua franca, a internet i mediji danas se smatraju središnjim mjestom mišljenja, osobito u oblikovanju jezika i kulture preko digitalne komunikacije. U kontekstu teorijskih spoznaja, živimo u digitalnoj, vizualnoj kulturi pa je notorno da slike potiču želju za učenjem i upijanjem informacija općenito, a potom da posreduju u učenju jezika partikularno. Stoga se ovim radom evaluiraju ključna pitanja uložena truda i vizualne komunikacije u nastavi engleskoga jezika. Teorijski okvir podrazumijeva trud, imaginaciju i kogniciju kao neposredno vezane uz multimediju te kao međusobno nadopunjavajuće u kontekstu učenja jezika. Ovime se ujedno poziva na daljnju kulturološko-jezičnu raspravu jednako važnu za učenje jezika kao i za razvijanje kritičkoga promišljanja u današnjemu društvu. Kako multimodalne reprezentacije diskurzivno pogoduju usvajanju jezika, potvrdili smo primjerima iz prakse u odnosu na poticanje na učenje i usvajanje koncepata unutar društvenoga konteksta. Uložen trud ovisit će tada o povećanu interesu i fundusu znanja ispitanika, a stjecanjem sigurnosti pri korištenju jezika jačat će želja za učenjem. Iz toga proistječe poveznica multimedije i truda u nastavi, a čine ga teorijski okvir koji pružaju sociosemiotika i/ ili sociolingvistika te praksis unutar društveno-humanističke sfere. $\mathrm{Na}$ koncu, istraživanja ovoga tipa predstavljaju neposrednu sadašnjost (nedavno smo svjedočili nužnu ostajanju kod kuće i ovisnosti o medijima te isključivo online nastavi uslijed pandemije koronavirusa ${ }^{3}$ ), a samim time i budućnost (mogućnost ponovne pojave ovakve ili slične pandemije u trenutku pisanja ovoga rada ostavljena je otvorenom). ${ }^{4}$ Združeni vid online i face-to-face nastave nameće se kao relevantan pristup koji pridonosi kvaliteti učenja engleskoga jezika. Stoga se nastavak istraživanja na ovu temu u domaćoj i inozemnoj znanstvenoj zajednici smatra nužnim

Kao što je ranije navedeno, razdobljem zaraze i stroge (samo)izolacije te zabrane kretanja (engl. the lockdown) službeno se smatra razdoblje od 18. ožujka 2020. do 1. svibnja 2020., <https://www.zagreb.hr/vazna-obavijest-covid19/156368>; (Hrvatski Zavod za javno zdravstvo, <https://www.hzjz.hr/sluzba-epidemiologija-zarazne-bolesti/ koronavirus-najnovije-preporuke/>.

${ }_{4}$ Službene stranice Vlade Republike Hrvatske, <https://www.koronavirus.hr/>. 
i poželjnim. U svezi s tim, preporuke su da se ponovi ovo istraživanje na većemu broju ispitanika u društvenim i humanističkim sferama te da se proširi na ostala sveučilišta kako bi se usporedili rezultati i iskustva.

\section{Literatura}

- Bird, Allan et. al. (1999) „Adapting and adjusting to other cultures: What we know but don't always tell“, Journalof Management Inquiry, vol. VIII, no. 2, pp. 152 - 165, https://journals.sagepub. com/doi/10.1177/105649269982009

- Bruno, Giuliana (1997) „Site-seeing: Architecture and the Moving Image“, Wide Angle, Ohio University School of Film, vol. XIX, no. 4, pp. $8-24$

- Burn, Andrew - Parker, David (2003) Analysing Media Text, Continuum, London.

- Burke, Peter (2003) Očevid - upotreba slike kao povijesnog dokaza, Izdanja Antibarbarus, Zagreb.

- Crystal, David (2007) How Language Works, Penguin Books, London.

- Crystal, David (2018) The Cambridge Encyclopedia of the English Language, Cambridge University Press, London.

- Dornyei, Zoltan (2005) The Psychology of the language learner. Individual Differences in Second Language Acquistion, Lawrence Erlbaum, Mahwah.

- Dornyei, Zoltan - Csizer, Kata (1998) „Ten commandments for motivating language learners: Results of an empirical study", Language Teaching Research, vol. II, pp. 203 - 229.

- Garcia-Pinar, Aranxa (2019a) „The influence of TED Talks on ESP undergraduate students' L2 motivational Self-System in the speaking skill: A mixed-method study", ESP TODAY, Journal of English for Specific Purposes at Tertiary Level, vol. VII, no. 1, pp. $231-253$. 
- Garcia-Pinar, Aranxa (2019b) „Encouraging engineering undergraduates to voice their ideas worth sharing", Multidisciplinary Journal for Education, Social and Technological Sciences, vol. VI, no. 1, pp. $25-45$.

- Gardner, Howard (2011) Frames of Mind, BasicBooks, New York.

- Gardner, Robert, C. (1985) Social Psychology and Second Language Learning: Ther Role of Attitudes and Motivation, Arnold, E., London, pp. $163-175$.

- Gardner, Robert, C. (1988) „The socio-educational model of second-language learning: assumptions, findings, and issues", Language Learning, vol. XXXVIII, pp. $101-126$.

- GOODWYN, ANDY (ed.) (200o) English in the Digital Age, Cassel, London - New York.

- Harnett, Maggie Katherine (2016) „The Importance ofMotivation in Online Learning", <https://www.researchgate.net/publication/315033704_The_Importance_of_Motivation_in_Online_Learning >, (30. VI. 2020.).

- ISTIFCI, ILKNUR (2017) „Perceptions of Turkish EFL students on online language learning platforms and blended language learning", Journal of Education and Learning, vol. VI, no. 1, pp. 113 $-121$.

- Jewitt, CARol et. al. (2016) Introducing Multimodality, Routledge, London - New York.

- Kress, Gunther (1988) Social Semiotics, Polity Press, Cambridge.

- Kress, Gunther - Van Leeuwen, Theo (1996, 200o) Reading Images: The Grammar of Visual Design, Routledge, London New York.

- Kress, Gunther (2001) Multimodal Discourse: The Modes and Media of Contemporary Communication, Arnold, London.

- Machin, David (2007) Introduction to Multimodal Analysis, Oxford University Press, New York. 
- Montiel-Chamorro, Marta L. (2018) "Comparing Online English Language Learning and Face-to-Face English Language Learning at El Bosque University in Colombia“, <https://scholarscompass.vcu.edu/etd/5343>, (30. VI. 2020.).

- Noth, Winfreid (2004) Priručnik semiotike, Ceres, Zagreb.

- Roell, Christine (2010) „Intercultural Training with Films“, English Teaching Forum, vol. XLVIII, no. 2, pp. 2 - 15.

- Rarick, Charles A. (2007) „Reflections on the Use of Foreign Film in the Classroom to Enhance Cross-Cultural Understanding", The Journal of Human Resource and Adult Learning, vol. III, pp. $1-6$.

- Siegel, Joseph (2015) Exploring Listening Strategy Instruction Through Action Research, Palgrave Macmillan, London.

- Službene stranice Grada Zagreba, <https://www.zagreb.hr/vazna-obavijest-covid19/156368>, (19. VI. 2020.).

- Službene stranice Hrvatskog zavoda za javno zdravstvo, <https:// www.hzjz.hr/sluzba-epidemiologija-zarazne-bolesti/koronavirus-najnovije-preporuke>, (19. VI. 2020.).

- Službene stranice Vlade Republike Hrvatske, <https://www.koronavirus.hr/>, (19. VI. 2020.).

- Trudgill, Peter (1988) Sociolinguistics: An Introduction to Language and Society, Penguin Books, London.

- Van Leeuwen, Theo (2005) Introducing Social Semiotics, Routledge, London - New York.

- Weiss, Edmond, H. (2005) The Elements of International English Style, M. E. Sharpe, Armonk - London.

- Zollo, Sole Alba (2019) „Instagram as a Pedagogical Tool to Enhance Undergraduate Students' Critical Thinking on Specialized Knowledge: A Qualitative Experiment“, Maci, Stefania - Sala, Michele (ed.), Representing and Redefining Specialised Knowledge: Variety in LSP, Cerlis Series vol. 8, pp. $245-280$. 
Original scientific article

Received on July 16, 2020

Accepted on April 6, 2021

Sunčana Tuksar - Moira Kostić Bobanović

Juraj Dobrila University of Pula

\section{INTERNET, MULTIMEDIA AND THE EFFORT PUT INTO LEARNING ENGLISH LANGUAGE}

\section{Abstract}

In the present globally networked society English language is lingua franca especially promoted by internet. In face-to-face teaching, and especially online teaching, media transfer information, language and culture, and therefore multimedia, or multimodal communication stands out as necessary for stimulating critical visual literacy and learning English language. That is the way it is because correlation of image and text intermediates in the manner which strengthens the individual's self-awareness of language and culture knowledge and activates his efforts and engagement in learning. Taking into consideration the above mentioned, this paper seeks to examine the following: a) the effort put into learning English language and b) ratio of the effort put into face-to-fa$c e$ and online teaching. The survey was conducted at the Juraj Dobrila University of Pula during the academic year 2019/2020, period of the obligatory staying at home because of Coronavirus pandemic. Such and similar research will be in the future important for permeation of media represented information as well as for expansion or replacement of face-to-face teaching in usual communication circumstances or in the circumstances when online teaching is the only option.

Keywords: English; multimedia; information and communication; face-to-face; online; effort 